\title{
Towards transcolonial francophone connections
}

Lewis, Jonathan

\section{Francosphères}

DOI:

10.3828/franc.2018.6

Published: 13/06/2018

Peer reviewed version

Cyswllt i'r cyhoeddiad / Link to publication

Dyfyniad o'r fersiwn a gyhoeddwyd / Citation for published version (APA):

Lewis, J. (2018). Towards transcolonial francophone connections: Representations of mobility and immobility in Bel-Avenir by Akli Tadjer. Francosphères, 7(1), 87-101.

https://doi.org/10.3828/franc.2018.6

\section{Hawliau Cyffredinol / General rights}

Copyright and moral rights for the publications made accessible in the public portal are retained by the authors and/or other copyright owners and it is a condition of accessing publications that users recognise and abide by the legal requirements associated with these rights.

- Users may download and print one copy of any publication from the public portal for the purpose of private study or research.

- You may not further distribute the material or use it for any profit-making activity or commercial gain

- You may freely distribute the URL identifying the publication in the public portal ?

Take down policy

If you believe that this document breaches copyright please contact us providing details, and we will remove access to the work immediately and investigate your claim. 


\title{
Towards transcolonial francophone connections: representations of mobility and immobility in Bel-Avenir by Akli Tadjer
}

\author{
Jonathan Lewis \\ University of Liverpool
}

This article analyses the representation of cross-cultural connections in Bel-Avenir (2006) by Franco-Algerian author Akli Tadjer. More specifically, and with reference to Françoise Lionnet's concept of 'transcolonialism', the article argues that the text constitutes a site of transcolonial francophone connection. Through exploring the transcolonial nature of the text, I posit a move beyond viewing the literary output of second-generation Franco-Algerian authors as defined only by the binary relationship between France and Algeria, that relationship itself defined as static and immutable. Furthermore, I argue that it is through the use of motifs of mobility and immobility that these broader francophone transcolonial connections are brought to light. Drawing on both established and more recent theories of mobility and travel, the article challenges the simplistic tendency to equate mobility with freedom, underlining that it is not sufficient simply to extol the enabling potential of mobility, as scholars such as Gilles Deleuze and Félix Guattari have done in the past. Rather, representations of the effects of migration in Tadjer's text underline the syncretization of mobility and immobility in the modern world. Crucially, it is through the syncretization of mobility and immobility that transcolonial connections are put forward in the text, challenging the rigidity of singular notions of identity, history and literature.

Keywords: mobility/immobility, transcolonialism, immigration, Franco-Algerian literature, postcoloniality

Cet article a pour objet d'analyser la représentation des relations interculturelles dans Bel-Avenir (2006), roman de l'auteur franco-algérien Akli Tadjer. En termes plus précis, l'article soutient, en tenant compte de la conception du 'transcolonialisme' avancée par Françoise Lionnet, l'idée que le texte constitue un lieu de relation francophone transcolonial. A travers l'exploration de la nature transcoloniale du texte, je postule que l'œuvre littéraire des auteurs de la seconde génération de l'immigration franco-algérienne ne devrait plus se limiter uniquement au lien entre la France et l'Algérie qui est, lui-même, présenté comme fixé et immuable. En outre, je prétends que le texte ne soit en mesure de mettre en relief l'ampleur des relations francophones transcoloniales que lorsqu'il emploie les motifs de mobilité et d'immobilité. Faisant appel à des théories avérées ainsi qu'à celles plus récentes de la mobilité et du voyage, l'article met en question la tendance simpliste d'assimiler la mobilité à la liberté, soulignant qu'il ne suffit plus à vanter le potentiel progressiste de la mobilité à la manière de Gilles Deleuze et Félix Guattari par exemple. Les représentations des effets de l'immigration dans le texte de Tadjer soulignent plutôt la syncrétisation de la mobilité et de l'immobilité dans le monde actuel. Fait décisif, c'est grâce à la syncrétisation de la mobilité et de l'immobilité que le texte met en lumière des relations transcoloniales et, ce faisant, remet en cause la rigidité de notions singulières de l'identité, de l'histoire et de la littérature.

Mots-clés: mobilité/immobilité, transcolonialisme, immigration, littérature francoalgérienne, postcolonialité 


\section{From Franco-Algerian to transcolonial connections}

Writing by the children of Algerian immigrants to France has, since the early 1980s, constituted an important site for the expression of the transpolitical condition that unites France and Algeria, with this body of work highlighting the porosity of national boundaries. According to Paul Silverstein, the history shared by France and Algeria, including over a century of French colonial rule that came to an end in 1962 after a brutal eight-year war for Algerian independence, has created a 'postcolonial predicament that unites Algeria and France into a single transpolitical space'. ${ }^{1}$ Moreover, Franco-Algerian immigrant literary expression constitutes one form of articulating an 'immigrant political subjectivity' that insists on expressing the transpolitics of France and Algeria. ${ }^{2}$ Building on Silverstein's work, this article analyses the representation of cross-cultural connections in the novel Bel-Avenir (2006) by Akli Tadjer, a French author of Algerian origin. It will explore specifically the representation of 'transcolonial' connections in Tadjer's text, positing a move beyond conceiving of second-generation Franco-Algerian authors and the body of work they have produced over the last three decades as defined only by the binary relationship between France and Algeria, a dichotomy which may have the consequence of presenting that relationship itself as static and immutable.

While Tadjer holds French, rather than Algerian, nationality, the place of his work, and indeed that of the generation of which he is representative, within the broad category of French national literature is problematic. As Michel Laronde has argued, such 'imagined' categories of national literature are 'inadequate to absorb the literatures

\footnotetext{
${ }^{1}$ Paul A. Silverstein, Algeria in France: Transpolitics, Race, and Nation (Bloomington: Indiana University Press, 2004), p. 2.

${ }^{2}$ Silverstein, p. 188.
} 
of immigration', ${ }^{3}$ which instead challenge traditional notions of an unmoving, monolithic national literature and national identity. It is with this view towards 'decentring' the conception of French national literature that Laronde uses the term 'Francophone literature', which he employs in order to re-evaluate France and French culture in relation to a wider French-speaking geopolitical space.

Such an understanding of the 'Francophone' had been elucidated earlier with the publication of Charles Forsdick's and David Murphy's landmark edited collection Francophone Postcolonial Studies: A Critical Introduction (2003). Through the launch of the field of Francophone Postcolonial Studies, Forsdick and Murphy called for a more inclusive definition of the 'Francophone', which denotes 'a complex network of French-speaking (or, in certain cases, partially French-speaking) regions, countries and communities which together form a Francophone space'. This space includes France itself as well as French-speaking cultures across the world. Laronde applies this understanding of the 'Francophone' to literature, affirming that 'Francophone literature' should not refer to a (lesser) subcategory of French literature, but to all literature written in the French language, including that written by authors who conform to traditional conceptions of French nationality. Furthermore, Laronde identifies in particular the literary output of francophone authors of North African origin, often collectively referred to as Beur literature, as an important means of challenging hegemonic notions of French national literature, culture and history. Such a challenge leads to, as Laronde puts it, 'a French cultural space [that] no longer stands alone with

\footnotetext{
${ }^{3}$ Michel Laronde, 'Displaced Discourses: Post(-)coloniality, Francophone Space(s), and the Literature(s) of Immigration in France', in H. Adlai Murdoch and Anne Donadey (eds), Postcolonial Theory and Francophone Literary Studies (Gainesville: University Press of Florida, 2005), pp. 175-92 (p. 179).

${ }^{4}$ Charles Forsdick and David Murphy, 'Introduction: The Case for Francophone Postcolonial Studies', in Charles Forsdick and David Murphy (eds), Francophone Postcolonial Studies: A Critical Introduction (London: Arnold, 2003), pp. 1-14 (p. 3).
} 
regard to, and in opposition to, a francophone diaspora with its many cultures'. Rather, France has 'become part of a larger francophone space that now includes it'. 5

Francophone writers of North African origin - such as Tadjer, Azouz Begag, Mehdi Charef, Mounsi, Leïla Sebbar, Tassadit Imache, Mehdi Lallaoui, Soraya Nini, Faïza Guène and Nina Bouraoui - thus contribute to the destabilizing and de-centring of a monolithic, unchanging and exclusive conception of French literature, culture and the French nation. As a result, this generation of authors has elicited much scholarly attention, particularly for its representation of hybrid identities, challenging traditional, singular notions of French identity and culture. ${ }^{6}$ The present article's analysis of a hitherto under-explored text (and indeed writer) focuses its attention on the motifs of mobility and immobility, representations of which have not been analysed extensively in the existing scholarship on francophone writers of North African origin. Drawing on both established and more recent theories of mobility and travel, which underline the syncretization of mobility and immobility in the modern world, the article will argue that it is through this syncretization of mobility and immobility that Tadjer challenges the rigidity of singular notions of identity, history and literature. Furthermore, the representation of (im)mobilities in Tadjer's text allows for a move beyond binary, Franco-Algerian or Franco-North African postcolonial connections, putting forward instead transcultural, transcolonial francophone connections.

For Alec Hargreaves, the notion of transculturation proves more enabling than the related but potentially limiting concept of transnationalism when it comes to reconceiving the discipline of French Studies. As Hargreaves notes, while

\footnotetext{
${ }^{5}$ Laronde, 'Displaced Discourses', p. 176.

${ }^{6}$ See for example Michel Laronde, Autour du roman beur: immigration et identité (Paris: L'Harmattan, 1993); Alec G. Hargreaves, Immigration and Identity in Beur Fiction: Voices from the North African Community in France, rev. edn (Oxford: Berg, 1997); Laura Reeck, Writerly Identities in Beur Fiction and Beyond (Lanham: Lexington Books, 2011).
} 
transnationalism signals the 'outmoded privileging of "national" distinctions', there is also a 'risk of transnationalism being misunderstood to mean the privileging of interconnections between state-bounded spaces, relegating other cultural fields to secondary status'. The transcultural, on the other hand, allows for the understanding that 'France and the wider French-speaking world are shot through with linguistic and other cultural currents whose contours do not match up with state boundaries': transculturation signals 'the breadth of the cultural horizons we are embracing'?

By viewing 'cultures of French expression both in interaction with each other and in dialogue with cultural spaces in other languages', ${ }^{8}$ Hargreaves also echoes Françoise Lionnet's notion of transcolonialism, which moves beyond postcolonialism by challenging the 'nineteenth-century teleological approach' implicit in the 'series of contested "posts" that has marked intellectual history since the second half of the twentieth century. ${ }^{9}$ For Lionnet, the benefits of 'transcolonialism', as opposed to 'postcolonialism', lie in the 'spatial dimension implicit in the prefix trans-'. This resort to 'spatial thinking, to a relational approach that takes the form of networks among sites marked differentially by the imperial project and the colonial will to power, permits a shift in focus and an alteration in perspective'. ${ }^{10}$ Lionnet takes Los Angeles as an example of such a 'transcolonial universe', with its immigrant communities from Latin America, from other parts of the United States and from across the Pacific Ocean. ${ }^{11}$ Such networks, she remarks, may still be marked 'by the residues of imperial

\footnotetext{
${ }^{7}$ Alec G. Hargreaves, 'The Transculturation of French Studies: Past, Present, and Future', Bulletin of Francophone Postcolonial Studies, 3.1 (2012), 2-8 (p. 7).

${ }^{8}$ Hargreaves, 'The Transculturation of French Studies', p. 8. My italics.

${ }^{9}$ Françoise Lionnet, 'Transnationalism, Postcolonialism or Transcolonialism? Reflections on Los Angeles, Geography, and the Uses of Theory', Emergences, 10.1 (2000), 25-35 (p. 31).

${ }^{10}$ Lionnet, p. 31.

${ }^{11}$ Lionnet, p. 29.
} 
domination', but also gesture towards a move 'outside of the orbit of direct European lines of contemporary influence'. ${ }^{12}$

While I recognize the merits of both the notions of the transcultural and the transcolonial in enabling reflection on the myriad relationships between cultures and in reconceiving the discipline of French Studies in an increasingly connected world, it is the latter that proves most relevant to my analysis in this article. Unlike much literature published by the children of Algerian migrants in France which, as Silverstein intimates, focuses on the transpolitical condition that unites France and Algeria, BelAvenir presents links between the metropolitan centre and former colonial spaces, such as Rwanda and New Caledonia, as well as Algeria. Brief consideration of some of Tadjer's previous work highlights the preoccupation specifically with Franco-Algerian relations, as opposed to the broader transcolonial connections we encounter in BelAvenir. His first novel, Les A.N.I. du "Tassili" (1984), ${ }^{13}$ is set on a ferry, the Tassili, which journeys between Algeria and France, allowing the author to '[posit] FrancoAlgerian relations as a dialogue by focusing on the lead protagonist Omar's many conversations with fellow passengers from both shores'. ${ }^{14}$ This depiction of 'different societal groups connected to both postcolonial countries ${ }^{15}$ is reprised in another of his works, Le Porteur de cartable (2002), ${ }^{16}$ which is set in France during the Algerian War and portrays the developing friendship between the young first-person narrator, again named Omar, who does odd jobs for the Front de Libération Nationale (FLN), and Raphaël, a pied-noir who has had to flee Algeria. While the cross-cultural connections presented in these two earlier texts by Tadjer focus solely on Franco-Algerian relations,

\footnotetext{
12 Lionnet, p. 29.

${ }^{13}$ Akli Tadjer, Les A.N.I. du "Tassili”" (Paris: Seuil, 1984).

${ }^{14}$ Edward Welch and Joseph McGonagle, Contesting Views: The Visual Economy of France and Algeria (Liverpool: Liverpool University Press), p. 123.

${ }^{15}$ Welch and McGonagle, p. 123.

${ }^{16}$ Akli Tadjer, Le Porteur de cartable (Paris: Jean-Claude Lattès, 2002).
} 
Bel-Avenir depicts a more complex transcolonial francophone rhizomatic network. By exploring these transcolonial connections in a text by a French author of Algerian origin, the article sheds fresh light on this generation of authors, encouraging an exploration of the transcolonial connections offered by their literary output and a move beyond viewing these texts as defined only by the transpolitical condition that unites France and Algeria.

As well as elucidating transcolonial francophone connections, as opposed to only Franco-Algerian connections, another aspect of Bel-Avenir that differentiates it from much of the literary output of the children of Algerian immigrants is the way in which it positions the protagonist of the novel in a relatively comfortable economic and social position. Particularly in the 1980s and 1990s, texts by French writers of Algerian origin were very much marked by a tendency to depict experiences of inequality, as an expression of the socioeconomic marginalization that prevented populations of immigrant origin to participate fully in French social, political and cultural life. Some of the most successful examples of what, in the 1980s, came to be known as Beur literature, such as Le Thé au harem d'Archi Ahmed (1983) by Mehdi Charef, and Le Gone du Châ̂ba (1986) and Béni ou le paradis privé (1989) by Azouz Begag, ${ }^{17}$ provide evidence of this representation of marginalization and concomitant challenge to traditional conceptions of singular French identity. Over the course of the 1990s and into the first decade of the twenty-first century, the work of writers such as Mounsi, Rachid Djaïdani and Abdel Hafed Benotman, as well as Charef and, as we have seen, Tadjer himself, continued this trend of depicting conditions of socioeconomic marginalization and, in some cases, linking this marginalization to the afterlives of

\footnotetext{
${ }^{17}$ Mehdi Charef, Le Thé au harem d'Archi Ahmed (Paris: Mercure de France, 1983); Azouz Begag, Le Gone du Chaâba (Paris: Seuil, 1986); Azouz Begag, Béni ou le paradis privé (Paris: Seuil, 1989).
} 
colonization and the Algerian War. Focus on the war - still the central event in defining the relationship between France and Algeria - in texts such as Le Voyage des âmes (1997) by Mounsi, La Seine était rouge (1999) by Leïla Sebbar and À bras-le-cour (2006) by Charef, ${ }^{18}$ exemplify the tendency towards depicting binary Franco-Algerian connections.

In Bel-Avenir, reference to the war is eschewed and representations of socioeconomic marginalization are restricted to occasional evocations of the narratorprotagonist's past. For example, the text opens with the narrator (once again named Omar) celebrating his new employment, leading a friend of his, Godasse, to exclaim: 'Tu vas enfin pouvoir t'installer dans le durable'. ${ }^{19}$ Both Omar and Godasse, of Polish immigrant origin, are in fact former residents of the Bel-Avenir HLM (Habitation à loyer modéré), an ironically-named, low-cost housing estate, and Godasse's remark that Omar is finally finding permanency ('le durable') through employment points towards the escape of both characters from figurative and physical entrapment on the margins of French society. Indeed, the HLM blocks located on the peripheries of France's big cities have constituted another recurring motif in the literary output of French authors of Algerian origin since the 1980s, linking physical marginalization with a lack of access to adequate employment and housing. ${ }^{20}$ Though the circumstances of his employment are somewhat questionable - he has only been successful because his boss is determined to practise positive discrimination after being inspired by a speech by

\footnotetext{
${ }^{18}$ Mounsi, Le Voyage des âmes (Paris: Stock, 1997); Leïla Sebbar, La Seine était rouge: Paris, octobre 1961 (Paris: Thierry Magnier, 1999); Mehdi Charef, À bras-le-cœur (Paris: Mercure de France, 2006). ${ }^{19}$ Akli Tadjer, Bel-Avenir (Paris: Flammarion, 2006), p. 11.

${ }^{20}$ For more detailed discussion on the association between physical and figurative marginalization experienced by populations of immigrant origin in France, including representations of such associations in literature, see Michel Laronde, 'Urbanism as Discourse of Cultural Infiltration in Post-Colonial Fiction in France', Nottingham French Studies, 1 (2000), 64-78; Richard L. Derderian, North Africans in Contemporary France: Becoming Visible (New York: Palgrave Macmillan, 2004);

Alec G. Hargreaves, Multi-Ethnic France: Immigration, Politics, Culture, and Society (London and New York: Routledge, 2007).
} 
none other than Nicolas Sarkozy - any sense that Omar has been affected by physical and socioeconomic marginalization is consigned to his past and, while he is well aware of continuing inequalities and discrimination in French society (his response to his boss's attitude towards positive discrimination is indicative of this awareness), he does not experience the kind of social and cultural exclusion that dominates much literature by the children of Algerian migrants in France.

The relative stability of the Franco-Algerian narrator in Bel-Avenir is set in counterpoint to representations of mobile subjects, and it is to the use of motifs of mobility and immobility in Tadjer's novel that the present analysis now turns. It will be argued that it is through the use of such motifs and, more specifically, the syncretization of mobility and immobility, that broader francophone transcolonial connections are brought to light in the text.

\section{Mobility and immobility}

The catalyst for the representation of mobile subjects in Bel-Avenir is the nascent romantic relationship between Omar and Angélina, a Burkinabe immigrant who has moved to France but has yet to receive her carte de résident, and is therefore caught in an in-between state of permanent transience that is characteristic of the mobile subjects we encounter in Tadjer's novel. Representations of mobility in the novel do not, therefore, appear to reflect the enabling potential ascribed to mobility in works from the 1980s and 1990s by Gilles Deleuze and Félix Guattari, Rosi Braidotti, and Homi Bhabha, in which mobility is posited as a means to challenge hegemonic, singular notions of national identity and culture. ${ }^{21}$ Rather, as Dick Pels and, more recently,

\footnotetext{
${ }^{21}$ See for example Gilles Deleuze and Félix Guattari, Mille Plateaux (Paris: Éditions de Minuit, 1980); Rosi Braidotti, Nomadic Subjects: Embodiment and Sexual Difference in Contemporary Feminist Theory (New York: Columbia University Press, 1994); Homi Bhabha, The Location of Culture (London: Routledge, 1994).
} 
Elizabeth Lowenstein have noted, it is largely privileged, middle class, political exiles who have unsettled the rigid boundaries of national identities and promoted enabling notions of hybridity, rather than those who are impelled by natural disaster, war or extreme poverty to leave their culture of origin and seek their fortunes elsewhere. ${ }^{22}$ Thus, both Pels and Lowenstein warn that there are limits to viewing mobility as a solely positive means to challenge dominant, monolithic notions of identity and culture, since not all those who travel are in a sufficiently privileged position to enact such challenges. Furthermore, recent scholarship in the field of mobility studies has strived to highlight the link between mobility and immobility in past and contemporary global power relations, and has challenged the simplistic tendency to equate mobility with freedom. ${ }^{23}$ Rather, as Beverley Skeggs puts it, "mobility is a resource to which not everyone has an equal relationship'. ${ }^{24}$ These observations emphasize that it is not sufficient simply to extol the enabling potential of mobility as others have done in the past, and underline the need to acknowledge that 'the colonial world economy has long entailed extensive global mobilities [...] and, crucially, continues to entail many forms of immobility, both voluntary and forced' ${ }^{25}$

The representation of mobile subjects in Bel-Avenir reminds us of the syncretization of mobility and immobility, especially for those who travel to escape war or poverty and then are largely confined to the poorest areas of their host society. The

\footnotetext{
${ }^{22}$ See Dick Pels, 'Privileged Nomads: On the Strangeness of Intellectuals and the Intellectuality of Strangers', Theory, Culture \& Society, 16.1 (1999), 63-86, and Elizabeth Lowenstein, 'Even Nomads Need Passports: Representations of the State in Francophone Writings by Iranian Women', Bulletin of Francophone Postcolonial Studies, 6.1 (2015), 11-19.

${ }^{23}$ See, for example, Mimi Sheller, 'Mobility, Freedom and Public Space', in Sigurd Bergmann and Tore Sager (eds), The Ethics of Mobilities: Rethinking Place, Exclusion, Freedom and Environment (Farnham: Ashgate, 2008), pp. 25-38.

${ }^{24}$ Beverley Skeggs, Class, Self, Culture (London: Routledge, 2004), p. 49.

${ }^{25}$ Mimi Sheller, 'The New Mobilities Paradigm for a Live Sociology', Current Sociology Review, 62.6 (2014), 789-811 (p. 794).
} 
suggested permanence of Angélina's state of transience, and its association with continuous mobility, is underlined in the text as follows:

De nuit blanche en aube crasseuse, Angélina avait dérivé dans le dix-neuvième arrondissement de Paris puis échoué dans un squat de la rue de Tanger. Elle avait fait une demande de carte de résident à la préfecture. Des lunes et des lunes qu'elle attendait un signe. $^{26}$

Unable to find accommodation or a permanent job, both of which are linked to the lack of a resident card, Angélina has to settle for the most provisional, makeshift housing. Introducing Omar to her 'petit logement [composé] de bric et de broc', furnished with 'des chaises de camping dépareillées' and 'des poufs rapiécés', she remarks that she lives 'dans le provisoire comme tous les gens sur le qui-vive'. ${ }^{27}$ These 'gens sur le quivive', the sans-papiers who are subject to a never-ending wait to learn if they can remain in France while avoiding the threat of expulsion, comprise not only Angélina, but other migrants from sub-Saharan Africa and the wider francophone world. For example, Angélina reveals that she has taken the place of a cousin of hers, who was forced to vacate the room in which she now lives after being sent back to Mali. A continuous line of migration and expulsion is thus drawn between the former metropolitan centre and peripheral postcolonial spaces, as migrants from sub-Saharan Africa arrive in France only to become entrapped in a transitory state before eventually being expelled.

The idea that migrants are caught in this situation of continual movement, with no fixity at the end of it, is encapsulated by the title of the local organization that provides aid to the sans-papiers: La Dérive des Continents. The organization is based in Angélina's squat in rue Tanger, described as 'une zone de non-droit', ${ }^{28}$ underlining

\footnotetext{
26 Tadjer, Bel-Avenir, p. 21.

${ }^{27}$ Ibid., p. 78.

${ }^{28}$ Ibid., p. 76.
} 
the area's clandestine, anarchic nature, situated outside the normal order of society. The image of the surrounding 'repaires des dealers de coke, de crack, d'ecstasy et de toutes sortes de saloperies' adds to the criminality and disorder of this zone of unlawfulness. The area is a site towards which mobile subjects from different continents drift ('deriver'), and that has become a lawless area. The association of rue Tanger with crime and violence is not exclusive to fiction, as the area was recently thrown into the spotlight as the alleged breeding ground for the radicalization of the Kouachi brothers, who organized the deadly terrorist attacks on the headquarters of Charlie Hebdo on 7 January $2015 .{ }^{29}$ Furthermore, reference to this particular street creates a cross-cultural, Franco-North African connection with rue Ahmed Chaïb, formerly rue de Tanger, in Algiers. The street in Algiers occupies a level of notoriety itself, as implied by the local adage 'le matin rue Tanger, le midi rue Manger, le soir rue Danger', and is subject to plans for regeneration. ${ }^{30}$ Moreover, the evocation of drifting in La Dérive des Continents implies a one-way movement towards France, the former metropolitan centre. Such evocations of binary postcolonial relationships, in which the former colonial centre retains its dominant, focal position, and the recurrence of negative connotations associated with movement and mobile subjects constantly on the move 'des clandestins à perpétuité' ${ }^{31}$ - are set up in the first half of the text, only to be challenged in the second half. This plot structure contributes to and emphasizes Tadjer's subversion of static, immutable, binary relationships between former colonizer and former colony. The de-centring of these relationships is enabled further by the use of motifs of mobility to illuminate broader francophone transcolonial connections.

\footnotetext{
29 'Ce que l'on sait sur la radicalisation des frères Kouachi', Le Monde, 10 January 2015 <http://www.lemonde.fr/societe/article/2015/01/09/ce-que-1-on-sait-sur-la-radicalisation-des-frereskouachi_4552422_3224.html> [accessed 16 April 2018]

${ }^{30}$ Sihem Oubraham, 'Alger-Centre: La rue de Tanger sera piétonne', El Moudjahid, 8 August 2016 <http://www.elmoudjahid.com/fr/actualites/97510> [accessed 16 April 2018]

31 Tadjer, Bel-Avenir, p. 76.
} 
Fittingly, given the above discussion of the way in which the aesthetics of the plot structure take effect, the enabling potential of mobility culminates in the final scene of Bel-Avenir. In this scene, Omar disrupts midnight mass at the Église Saint-Roch, one of Paris's largest and most iconic churches. In the text, the Christmas service is attended by pop stars, famous athletes, actors and television presenters, underlining the importance of this particular site for the occasion, but it is the presence of the Préfet Duvernoy that is anticipated most by Omar. His plan is to interrupt the service in order to manipulate the spirit of the occasion and gain sympathy for his new friends, the sanspapiers of rue Tanger, in front of the prefect of police, in the hope of forcing him to grant resident cards to the immigrants. Omar is successful in 'infiltrating' the church, light-heartedly dismissing the inevitable fears that he is leading a terrorist attack, and introducing a large group of sans-papiers into the church. It is not insignificant of course that the site chosen for this intrusion is an important Christian place of worship (Christianity being the majority religion in France) where high-ranking state officials, such as the prefect, are expected to convene. The occasion allows for the encounter between apparently settled and singular identities and cultures and more mobile, errant subjects, each of whom 'trimballe dans des sacs en plastique ses papiers, son histoire, sa mémoire'. ${ }^{32}$ The notion of carrying one's identity, history and memory with oneself highlights what scholars in the emerging field of Mobility Studies have identified as the 'complex interrelation between travel and dwelling, home and not-home' epitomized by migrants and diasporic populations, who are caught between movement and stasis. ${ }^{33}$ It also draws attention to the mobility of identities, histories and memories, reinforcing the capacity of mobile subjects to illuminate, as James Clifford has argued

\footnotetext{
32 Ibid., p. 202.

${ }^{33}$ Kevin Hannam, Mimi Sheller and John Urry, 'Editorial: Mobilities, Immobilities and Moorings', Mobilities, 1.1 (2006), 1-22 (p. 10).
} 
previously, 'an ongoing transnational network that includes the homeland not as something simply left behind but as a place of attachment in a contrapuntal modernity'. ${ }^{34}$ Such 'mobile' discourses and identities, Clifford elucidates, 'trouble the linear, progressivist narratives of nation-states and global modernization'. ${ }^{35}$ This challenge to linear narratives and the singular identities they promote is suggested in Tadjer's text through the reaction of the prefect's wife on seeing the crowd of sanspapiers enter the church: 'Elle craint pour les siens . . . tous ces métèques . . . Elle n'imaginait pas que ce fût possible [...] Elle n'imaginait pas que sa France soit dégradée à ce point-là'. ${ }^{36}$ Omar's reaction of leaving her to her disillusionment reaffirms the destabilizing of such outdated visions of unchanging, 'pure' identity and culture, which are 'infiltrated' and disrupted by the appearance of the crowd of mobile subjects at the church.

The ensuing clamour on the part of the sans-papiers as they demand for their immigration papers to be regulated further underlines the notion of mobile histories, which come together with dominant, franco-centric history to form new networks and spaces of connection between francophone identities. The first of the sans-papiers to confront the prefect is N'Gom, an African (a more precise country of origin is not specified) whose father and grandfather both fought for France in the World Wars. Pleading with the prefect to be granted legal stay in France, he displays a war medal that, he claims, De Gaulle himself had bestowed on his father. N'Gom is followed by a Tutsi refugee, who explains that he moved to France from Rwanda to seek political asylum, only to be sent to a detention centre and await expulsion. Another presents a

\footnotetext{
${ }^{34}$ James Clifford, Routes: Travel and Translation in the Late Twentieth Century (Cambridge, $\quad$ MA: Harvard University Press, 1997), p. 256.

${ }^{35}$ Clifford, p. 263.

36 Tadjer, Bel-Avenir, p. 205.
} 
photograph of an ancestor of his 'dans une cage [. . .] dans un zoo humain' at the Jardin d'acclimatation, where he died during the Exposition Coloniale of $1931 .^{37}$ This particular story alludes to the transportation of over a hundred Kanaks from New Caledonia to be exhibited at the Exposition, which has been represented more fully in literature by Didier Daeninckx's novel Cannibale (1998). In the above stories, the presentation of commemorative objects, such as the war medal and the photograph, underlines the notion of memories being transported with the various mobile subjects, who themselves embody histories in motion, coming together in this gathering at the end of Tadjer's text to challenge conceptions of linear, static, singular history, identity and culture.

In representing such an array of mobile subjects and mobile histories, this culminating scene of Bel-Avenir emphasizes the move beyond depicting only FrancoAlgerian connections in this text, and the elucidation of broader francophone transcolonial connections at work throughout Tadjer's novel. Crucially, not only are broader francophone connections brought to light, but they are at the same time decentred: the text illuminates connections between the metropolitan centre and peripheral postcolonial spaces, such as former French colonies in North Africa, subSaharan Africa or the Pacific Ocean, but also creates connections between all of these peripheral spaces themselves, creating a more complex francophone rhizomatic network involving not only Franco-Algerian mobile subjects, but also wider transhistorical and transcolonial spaces and subjectivities. A word of caution, however: the transcolonial network presented by Tadjer remains to a certain extent informed by a Eurocentric viewpoint, through the comments of the prefect's wife and indeed through Tadjer's lack of assigning a specific nationality to one of the sans-papiers,

\footnotetext{
${ }^{37}$ Ibid., pp. 207.
} 
which risks conforming to common misconceptions of Africa and Africans as singular homogenous entities. By lamenting the appearance of 'tous ces métèques', the prefect's wife herself homogenizes the formerly colonized mobile subjects who 'infiltrate' the franco-centric space represented by the Église Saint-Roch, defining the 'other' in contradistinction to the French/European self. Tadjer's textualization of transcoloniality in Bel-Avenir thus alerts us to the persistence of Eurocentric modes of thinking, complicating Lionnet's concept that transcolonialism occurs 'outside of the orbit of direct European lines of contemporary influence' ${ }^{38}$

Despite the above reservations, it would still be more appropriate to conceive of Bel-Avenir as a site of 'transcolonial', rather than 'postcolonial', encounter and interconnectivity. By placing attention on space, rather than time, transcolonialism shifts our focus away from the notion of spaces and subjectivities affected by colonization as being forever and solely defined by colonization. Rather, transcolonialism, while recognizing the important ramifications of the colonial encounter for spaces that may always be defined to a certain extent by colonialism, also allows for an alternative, de-centred perspective, as different spaces and subjectivities affected by colonization come into contact, creating connections that do not only rely on European power structures. Thus, we can consider the 'transcolonial universe' of Los Angeles, as Lionnet does, or the transcolonial network represented at the end of Bel-Avenir, where connections are made between not only the metropolitan centre and former colonial spaces, such as Rwanda and New Caledonia, as well as North Africa, but between these francophone spaces themselves. By permitting connections between different former colonial spaces, and not only between former colonies and France,

\footnotetext{
${ }^{38}$ Lionnet, p. 29.
} 
Tadjer's text allows for a de-centring of the relationship between former colony and former metropolitan centre.

\section{Conclusion}

My discussion of transcolonial connections in Bel-Avenir has sought to indicate a move beyond conceiving of authors of Algerian immigrant origin and the body of work they have produced over the last three decades as defined only by the binary relationship between France and Algeria, that relationship itself defined as static and immutable. While Franco-Algerian immigrant literary expression has constituted, as Silverstein rightly argues, a form of articulating an 'immigrant political subjectivity' that insists on expressing the transpolitics of France and Algeria, ${ }^{39}$ my reading of Bel-Avenir puts forward the possibility of reconceiving the literary output of second-generation FrancoAlgerian authors as part of a broader category of transcolonial literature in French. Transcolonial or transcultural francophone literature can be placed in opposition to the notion of littérature-monde en français, put forward in a manifesto published in Le Monde in 2007. While the manifesto 'attempt[ed] to define a transcultural literary corpus that challenges or ignores the boundaries of the nation state', ${ }^{40}$ it was subsequently criticized for presenting 'an exoticising vision that continues to privilege the publishing industry of the metropolitan centre of the former empire' ${ }^{41}$ For Lydie

\footnotetext{
${ }^{39}$ Silverstein, p. 188.

${ }^{40}$ Alec G. Hargreaves, Charles Forsdick and David Murphy, 'Introduction: What Does LittératureMonde Mean for French, Francophone and Postcolonial Studies?', in Alec G. Hargreaves, Charles Forsdick and David Murphy (eds), Transnational French Studies: Postcolonialism and LittératureMonde (Liverpool: Liverpool University Press, 2010), pp. 1-11 (p. 4).

${ }^{41}$ Hargreaves, Forsdick and Murphy, p. 1. See also Roger Célestin, 'Littérature-Monde: Of Concepts Big and Little', Irish Journal of French Studies, 11 (2011), 135-45; Jacqueline Dutton, 'État Présent: World Literature in French, Littérature-Monde, and the Translingual Turn', French Studies, 70.3 (2016), 404-18. For the full manifesto, see 'Pour une "littrature-monde" en français', Le Monde, 15 March 2007 $<$ http://www.lemonde.fr/livres/article/2007/03/15/des-ecrivains-plaident-pour-un-roman-en-francaisouvert-sur-le-monde_883572_3260.html> [accessed 16 April 2018]
} 
Moudileno, the manifesto's reproduction of centre/periphery divides lay in its 'valorization of mobility', which ended up 'transforming an opening-up gesture into an exclusionary one'. ${ }^{42}$ The manifesto thus assigned too much value to mobility, benefiting those who are privileged enough to move easily around the world, but maintaining the marginal status of those who are already marginalized. Those left on the periphery include the majority of francophone writers, who may not necessarily move as freely or as easily around the world as some of the celebrated francophone authors to have lent their support to the littérature-monde manifesto, ${ }^{43}$ but who may nonetheless illuminate broader, global transcultural or transcolonial connections in their work, as Tadjer does in Bel-Avenir. Unlike the conception of littérature-monde put forward a decade ago, transcolonial francophone literature underlines 'the residues of imperial domination', ${ }^{44}$ but also attempts to de-centre power structures inherited from colonialism, as Tadjer does by highlighting the persistence of forms of mobility and immobility. Transcolonialism thus enables a move beyond 'universalized' definitions of culture and literature and the reproduction of static, immutable binary paradigms for which the 'Pour une littérature-monde en français' manifesto has been criticized.

Finally, considering the transcolonial and transcultural aspects of literatures written in French offers ways out of the 'post-colonial problematic', inherent in which is the danger, as Hargreaves and Mark McKinney warned almost a decade ago, of 'reifying the very categories which [postcolonial] minorities seek to relativize and/or

\footnotetext{
${ }^{42}$ Lydie Moudileno, 'Francophonie: Trash or Recycle?', in Hargreaves, Forsdick and Murphy, Transnational French Studies, op. cit., pp. 109-24 (p. 119).

${ }^{43}$ Moudileno, p. 118. Prominent and successful francophone authors to have signed the manifesto included Nancy Huston, Alain Mabanckou, Tahar Ben Jelloun, Maryse Condé, Didier Daeninckx, Édouard Glissant, Dany Laferrière and Jean-Marie Gustave Le Clézio.

${ }^{44}$ Lionnet, p. 29.
} 
subvert' ${ }^{45}$ More recently, Forsdick and Murphy have reiterated that one of the more prominent and justified criticisms of postcolonial studies is its tendency to 'enclos[e] formerly colonized societies within a framework that ties them eternally to their former colonizers' ${ }^{46}$ The rejection of binary paradigms, such as between (former) colonizer and (former) colony, in Lionnet's conception of transcolonialism and its engagement with traditional centres of power without reproducing the dominance of those centres allows for the possibility of shifting the paradigm of postcolonial studies and of rethinking the way in which we view postcoloniality. By analysing the ways in which Bel-Avenir creates transcolonial connections between different former colonial spaces, de-centring the relationship between former colonies and former metropolitan centre, this article has shed fresh light on the literary output of second-generation FrancoAlgerian authors, highlighting the potential of this body of work to contribute to conceiving of the transcolonial and transcultural nature of French studies and of postcolonial studies.

\footnotetext{
45 Alec G. Hargreaves and Mark McKinney, 'Introduction: The Post-Colonial Problematic in Contemporary France', in Alec G. Hargreaves and Mark McKinney (eds), Post-Colonial Cultures in France (London: Routledge, 1997), pp. 3-25 (p. 22).

${ }^{46}$ Charles Forsdick and David Murphy, 'Situating Francophone Postcolonial Thought', in Charles Forsdick and David Murphy (eds), Postcolonial Thought in the French-Speaking World (Liverpool: Liverpool University Press, 2009), pp. 1-27 (p. 25).
} 


\section{Works Cited}

'Pour une "littrature-monde" en français', Le Monde (15 March 2007) <http://www.lemonde.fr/livres/article/2007/03/15/des-ecrivains-plaident-pourun-roman-en-francais-ouvert-sur-le-monde_883572_3260.html> [accessed 18 December 2017]

'Ce que l'on sait sur la radicalisation des frères Kouachi', Le Monde (10 January 2015) <http://www.lemonde.fr/societe/article/2015/01/09/ce-que-l-on-sait-surla-radicalisation-des-freres-kouachi_4552422_3224.html> [accessed 19 May 2017]

Begag, Azouz, Le Gone du Chaâba (Paris: Seuil, 1986)

Begag, Azouz, Béni ou le paradis privé (Paris: Seuil, 1989)

Bergmann, Sigurd, and Tore Sager (eds), The Ethics of Mobilities: Rethinking Place, Exclusion, Freedom and Environment (Farnham: Ashgate, 2008)

Bhabha, Homi, The Location of Culture (London: Routledge, 1994)

Braidotti, Rosi, Nomadic Subjects: Embodiment and Sexual Difference in Contemporary Feminist Theory (New York: Columbia University Press, 1994)

Célestin, Roger, 'Littérature-Monde: Of Concepts Big and Little', Irish Journal of French Studies, 11 (2011), 135-45

Charef, Mehdi, Le Thé au harem d'Archi Ahmed (Paris: Mercure de France, 1983)

Charef, Mehdi, À bras-le-cœur (Paris: Mercure de France, 2006)

Clifford, James, Routes: Travel and Translation in the Late Twentieth Century (Cambridge, MA: Harvard University Press, 1997)

Daeninckx, Didier, Cannibale (Paris: Gallimard, 1997)

Deleuze, Gilles, and Félix Guattari, Mille Plateaux (Paris: Éditions de Minuit, 1980) 
Derderian, Richard L., North Africans in Contemporary France: Becoming Visible (New York: Palgrave Macmillan, 2004)

Dutton, Jacqueline, 'État Présent: World Literature in French, Littérature-Monde, and the Translingual Turn', French Studies, 70/3 (2016), 404-18

Forsdick, Charles, and David Murphy (eds), Francophone Postcolonial Studies: A Critical Introduction (London: Arnold, 2003)

Forsdick, Charles, and David Murphy (eds), Postcolonial Thought in the FrenchSpeaking World (Liverpool: Liverpool University Press, 2009)

Hannam, Kevin, Mimi Sheller and John Urry, 'Editorial: Mobilities, Immobilities and Moorings', Mobilities, 1/1 (2006), 1-22

Hargreaves, Alec G., Immigration and Identity in Beur Fiction: Voices from the North African Community in France, rev. edn (Oxford: Berg, 1997)

Hargreaves, Alec G., and Mark McKinney (eds), Post-Colonial Cultures in France (London: Routledge, 1997)

Hargreaves, Alec G., Multi-Ethnic France: Immigration, Politics, Culture, and Society (London and New York: Routledge, 2007)

Hargreaves, Alec G., Charles Forsdick and David Murphy (eds), Transnational French Studies: Postcolonialism and Littérature-Monde (Liverpool: Liverpool University Press, 2010)

Hargreaves, Alec G., 'The Transculturation of French Studies: Past, Present, and Future', Bulletin of Francophone Postcolonial Studies, 3/1 (2012), 2-8

Laronde, Michel, Autour du roman beur: immigration et identité (Paris: L'Harmattan, 1993)

Laronde, Michel, 'Urbanism as Discourse of Cultural Infiltration in Post-Colonial Fiction in France', Nottingham French Studies, 1 (2000) 
Lionnet, Françoise, 'Transnationalism, Postcolonialism or Transcolonialism? Reflections on Los Angeles, Geography, and the Uses of Theory', Emergences, 10/1 (2000), 25-35

Lowenstein, Elizabeth, 'Even Nomads Need Passports: Representations of the State in Francophone Writings by Iranian Women', Bulletin of Francophone Postcolonial Studies, 6/1 (2015), 11-19

Mounsi, Le Voyage des âmes (Paris: Stock, 1997)

Murdoch, H. Adlai, and Anne Donadey (eds), Postcolonial Theory and Francophone Literary Studies (Gainesville: University Press of Florida, 2005)

Oubraham, Sihem, 'Alger-Centre: La rue de Tanger sera piétonne', El Moudjahid (8 August 2016) < http://www.elmoudjahid.com/fr/actualites/97510> [accessed 18 December 2017]

Pels, Dick, 'Privileged Nomads: On the Strangeness of Intellectuals and the Intellectuality of Strangers', Theory, Culture \& Society, 16/1 (1999), 63-86

Reeck, Laura, Writerly Identities in Beur Fiction and Beyond (Lanham: Lexington Books, 2011)

Roberson, Susan L. (ed.), Defining Travel: Diverse Visions (Jackson: University Press of Mississippi, 2001)

Sebbar, Leïla, La Seine était rouge: Paris, octobre 1961 (Paris: Thierry Magnier, 1999)

Sheller, Mimi, 'The New Mobilities Paradigm for a Live Sociology', Current Sociology Review, 62/6 (2014), 789-811

Silverstein, Paul A., Algeria in France: Transpolitics, Race, and Nation (Bloomington: Indiana University Press, 2004)

Skeggs, Beverley, Class, Self, Culture (London: Routledge, 2004) 
Tadjer, Akli, Les A.N.I. du "Tassili” (Paris: Seuil, 1984)

Tadjer, Akli, Le Porteur de cartable (Paris: Jean-Claude Lattès, 2002)

Tadjer, Akli, Bel-Avenir (Paris: Flammarion, 2006)

Welch, Edward, and Joseph McGonagle, Contesting Views: The Visual Economy of France and Algeria (Liverpool: Liverpool University Press) 